\title{
'Hidden' expatriates: international mobility in the United Arab Emirates as a challenge to current understanding of expatriation
}

Article

Accepted Version

Haak-Saheem, W. and Brewster, C. (2017) 'Hidden' expatriates: international mobility in the United Arab Emirates as a challenge to current understanding of expatriation. Human Resource Management Journal, 27 (3). pp. 423-439. ISSN 1748-8583 doi: https://doi.org/10.1111/1748-8583.12147 Available at https://centaur.reading.ac.uk/69486/

It is advisable to refer to the publisher's version if you intend to cite from the work. See Guidance on citing.

To link to this article DOI: http://dx.doi.org/10.1111/1748-8583.12147

Publisher: Wiley-Blackwell

All outputs in CentAUR are protected by Intellectual Property Rights law, including copyright law. Copyright and IPR is retained by the creators or other copyright holders. Terms and conditions for use of this material are defined in the End User Agreement. 


\section{CentAUR}

Central Archive at the University of Reading

Reading's research outputs online 


\section{'HIDDEN' EXPATRIATES: INTERNATIONAL MOBILITY IN THE UNITED ARAB EMIRATES AS A CHALLENGE TO CURRENT UNDERSTANDING OF EXPATRIATION}

Expatriates are often assumed to have enhanced terms and conditions and, since that makes them expensive, to be in key managerial or technical specialist roles. Employees who come from abroad and are in more manual or even menial roles are usually referred to as 'migrants'. However, there are millions of people around the world who are not migrants, their intended sojourn in a foreign country is seen by them and their employers as temporary, but their employment contracts are far from advantageous compared to locals. These 'hidden' expatriates are brought into focus in the emerging Arab Gulf States. In some of these countries the population consists mainly of expatriates, with the local population a small minority: These expatriates include many in lower-management or manual or menial jobs. We demarcate these expatriates from organisationally assigned expatriates, self-initiated expatriates and migrants. We use qualitative data from such expatriates in the United Arab Emirates to explore the issues this raises for governments, employers and the expatriates - and for our understanding of the phenomenon of expatriation.

Keywords: Expatriation; Hidden Expatriates; Arab Gulf countries; United Arab Emirates; Emiratization; Contextual Perspective 


\section{INTRODUCTION}

Given the constant growth of globalization and its political and economic implications, the process and management of expatriation has been a key issue in international human resource management (IHRM). Early studies researched employees assigned from their headquarters, usually in developed countries, to international operations (e.g. Adler, 2002; Hechanova, Beehr \& Christiansen, 2003; Tung, 1998) and, usually implicitly, defined 'expatriates' as those categorised as such by their employers and enjoying advantageous terms and conditions of employment (Lan, 2006). In addition to these organisationally assigned expatriates (AEs), Suutari and Brewster (2000) extended the definition to include self-initiated expatriates (SIEs), i.e. individuals who had made their own way to a job in another country and who were not employed on expatriate terms and conditions. More recent research accords increased interest toward migrants (Al Ariss \& Crowley-Henry, 2013) to advance our understanding of international work experience.

Fundamental to all definitions of expatriation are four assumptions (Suutari \& Brewster, 2000; Biemann \& Andresen, 2010; Andresen, Al Ariss \& Walther 2013; Vaiman \& Haslberger, 2013; Cerdin \& Selmer, 2014). Expatriates must:

- be relocated to a country of which they are not a citizen;

- intend to be there for a year or more but for their stay not to be permanent;

- have a regular job in the host country; and

- be skilled or professional employees.

It is this final assumption that we challenge in this paper. 
The literature has applied the term 'expatriate' to a breadth of distinct forms of international transfer across the globe. In addition to the AEs dispatched by large multinational enterprises (MNEs), there is now a rich theoretical discussion on alternative forms of international experience, including SIEs (see Andresen, Al Ariss \& Walther; Vaiman \& Haslberger, 2013), migrants (Al Ariss \& Crowley-Henry, 2013), short-term assignees (Tahvanainan, Worm \& Welch, 2005), business travellers and others (Konopaske, Robie \& Ivancevich, 2009; Andresen, Bergdolt, Margenfeld \& Dickmann, 2014). Not all of these fall within the usually understood definition of expatriates: for example, migrants arrive in the host country intending to stay, short-term assignees tend to stay for less than six months and certainly not more than a year, and business travellers do not relocate to the country at all. These are internationally mobile individuals but not expatriates.

For the expatriates themselves, given the increasing research interest, definitions and attempts at categorisation have tended to be non-analytical, increasing the lack of clarity and ambiguity (Baruch, Dickmann, Altman \& Bournois, 2013). Furthermore, as Suddaby (2010) and Vaiman and Brewster (2015) point out, much more attention needs to be paid to contextual conditions impacting on given constructs (see Gergen, 1982; Whetton 1989).

The particular case of the Arab Gulf States provides a less often studied context for expatriation and challenges one of the four taken-for-granted assumptions about expatriates. More specifically, our focus here is on expatriation in the United Arab Emirates (UAE), which constitutes - along with Bahrain, Kuwait, Oman, Saudi Arabia and Qatar - the Gulf Cooperation Council (GCC). Locals form only a minority of the population in the UAE. Recent research reveals that, $99 \%$ of employees in the private sector are foreigners (Al Waqfi \& Forstenlechner, 2014). Although there has been some analysis of the demographic characteristics within the Gulf States (Chammartin, 2004), this has not yet explored the implication of these demographic challenges for human 
resource management. The dominance of the international workforce across a wide range of jobs constitutes a unique environment challenging the existing expatriation literature. Rapid economic and social development has created a large demand for foreign employees in the Gulf in general and the UAE in particular attracts a wide range of individuals across all sections and levels of the economy. In these circumstances, expatriation has distinct implications for HRM theory and practice that we explore in this paper.

To do this, our paper explores the different types of expatriation in the UAE as follows. First, we outline the key assumptions underlying the notion of expatriates in the extant literature. Then we examine the position in the UAE. Next we explain the methodology we used to explore these issues. Given the lack of attention to the 'hidden' expatriates we expose in this study, we conducted qualitative research to identify their issues and clarify the distinctions between types of expatriate in the UAE. Then we present our findings and, finally, we discuss the challenge of our analysis for theory and practice and draw conclusions.

\section{LITERATURE ON EXPATRIATION}

Expatriation has been a significant issue in the scholarly study of business and management since the 1960s (Boudin, 1960; Oberg, 1963), and is important in international business (Black, Gregersen \& Mendenhall, 1992; Bonache \& Pla-Barber, 2005) and central to IHRM (Dowling, Festing \& Engel, 2008). IHRM has become more diverse, complex and nuanced. One of the central debates has been concerned with international assignments, with much of this literature devoted to organizationally assigned expatriation (Dorsch, Suutari \& Brewster, 2012; Adler, 2002; Hechanova, Beehr \& Christiansen, 2003; Collings, Scullion \& Morley, 2007).

In the literature, organizationally assigned expatriates (AEs) are deployed and sponsored by their MNE, with special terms and conditions of employment, and with head office arranging their 
repatriation (Suutari \& Brewster, 2000; Biemann \& Andresen, 2010). Traditionally, expatriation has been associated with the notion of the white, male manager on an international mission to spread his expertise and advance his career (Lan, 2006; Al Ariss et al., 2012), although attention has been paid to female expatriates (Harris, 2002; Varma, Toh \& Budhwar, 2006) and families (Haslberger \& Brewster, 2008; Abdul Malek, Budhwar \& Reiche, 2015). Throughout most of the expatriation literature there has also been a general assumption that expatriates are from developed countries and work in other developed countries or in the major cities of the underdeveloped countries, though that too is changing (Cheng \& Lin, 2009). In general, the literature is beginning to recognize the more complex nature of the international workforce (Al Ariss \& Crowley-Henry, 2013).

We follow a clear line of argument to challenge the boundaries of existing concepts by testing them in another context: the UAE.

\section{EXPATRIATION IN THE UAE}

In the Gulf States, the role of the state, the legal system and the employment market are critical forces and shapers of the international workforce (Haak-Saheem, Festing \& Darwish, 2016). As outlined in the few available publications, people from outside these countries are the dominant element of the workforce across the Gulf countries, ranging from a low of approximately $50 \%$ of the total population in Bahrain and Oman, to a high of over 90\% in the UAE and Qatar (Ewers, 2007).

Unlike many other fast-developing countries, the UAE began its growth trajectory without surplus labour or anything approaching an adequately sized labour force to meet the demand of a fast- 
growing country (Malecki \& Ewers, 2007). Lacking an indigenous skilled workforce, organizations were compelled to import labour. The ratio of nationals $(947,997)$ to foreigners $(7,316,073)$ is a rare and challenging phenomenon (Federal Competitiveness and Statistics Authority, 2014). Foreigners not only account for the vast majority of the working population but also for $84 \%$ of the total population of the UAE (Burgess, Connell \& Winterton, 2013), a ratio amongst the most disproportionate in the world (Forstenlechner, 2010; Hvidt, 2009).

To reduce the reliance on foreigners, governments across the GCC have attempted to enforce localisation policies (Al-Ali, 2008), including 'Emiratization' in the UAE (Forstenlechner \& Mellahi, 2011), including a range of policies designed to encourage and support the employment of nationals in preference to expatriates. Generally, however, employment for UAE citizens is still generated through the provision of high-wage public sector jobs; on average, Gulf nationals comprise $73 \%$ of the region's public sector labour forces (Forstenlechner \& Rutledge, 2010).

The unique circumstances of the UAE, with most of the population being non-nationals, means that there are foreigners in nearly all kinds of jobs there. The demographic characteristics of the Gulf States, and their attractiveness as a destination for low skilled expatriates from the subContinent (Atiyyah, 1996; Shah, 2004) have been explored. The strategic controlling, expertisetransferring jobs that exist are the same as those that have been the focus of scholarly research in 'expatriation studies'. However, there are also many more menial jobs, manual jobs and the lowerlevel office jobs. These jobs are filled by people from countries to the south or east of the Gulf States - from India, Pakistan, Nepal and Bangladesh and from Ethiopia. While these people have had some prominence in news reports and in reports from pressure groups, they have been so far either ignored in, or hidden from, scholarly expatriation research; defined out of existence (as not being 'highly qualified'). Nevertheless, these are people working in the GCC states, unable to 
become nationals, knowing that, willingly or unwillingly, they will have to return home within a few years. Note too that many, indeed the vast majority of them, are hired in by local businesses. They collaborate with employment agencies to find and bring in the labour that they need. Apart from the arguably empirically and historically based, but conceptually irrelevant, issue of skill levels, these people meet all the criteria of 'expatriation'.

These 'hidden expatriates', as we dub them, are like other expatriates, an important component of the workforce of nearly every organisation in the Gulf States, so they are subject to human resource management; and like other expatriates they come from other countries for a limited time and have no citizenship in the UAE, with their residency visa being connected to their employment contract. More specifically, a government-approved employment contract is the precondition of a resident visa in the UAE. Clearly they are not 'migrants' in the sense that they have no opportunity to remain in the country.

It would be possible to, in effect, insist on the 'skilled' criterion for expatriation and define these people out of our studies. That is in effect what has happened so far. This is not, of course, an option for human resource managers in the Gulf States. They still have to apply the full range of HRM policies and practices to these lower-skilled expatriates. As academics, we are in danger of narrowing the focus of study in the expatriation field to relatively wealthy, white Westerners and ignoring the reality of these other expatriates - whom, we note below, have many of the same concerns, problems and issues as anyone moving from one country to another to work for a limited period of time - and of eschewing study of a topic that is of serious import for local HRM specialists.

We need to uncover these 'hidden' expatriates and understand their issues and the consequent HRM policies and practices that apply to them. 


\section{METHODOLOGY}

Since there is limited knowledge on expatriation in the Gulf States in general and in the UAE in particular, especially about 'hidden' expatriation, a qualitative approach was the most appropriate methodological choice. The research is exploratory in nature and seeks to unearth an initial understanding of a particular type of expatriates that little is known about (see Hendry, 2003). The openness of the qualitative method enables data collection that is not constrained by predetermined categories of analysis and, thus, it allows for a level of depth and detail that quantitative methods cannot provide (Patton, 1990; Doz, 2011). Additionally, qualitative research encourages exploration of the importance of hitherto neglected phenomena and the relevance of a theoretical perspective (Weick, 1989).

\section{Sample and data collection}

Our sample was determined in order to investigate the phenomenon where is found to exist (Chenitz \& Swanson, 1986). At this stage, we collected, coded and analysed data simultaneously to understand which data to collect next (Glaser \& Strauss, 1967). More specifically, our ongoing data collection process was controlled by the emerging theory rather than a list of variables (Becker, 1983). In other words, our approach was based on the need to collect more data to examine categories and their relationships and to ensure that representativeness in the categories exists (Glaser \& Strauss, 1967; Chenitz \& Swanson, 1986). The full range of variation in the categories identifies the basis of the emerging theory (Strauss \& Corbin, 1997). This approach of gathering and exploring data allows the emergence of patterns (Patton, 1990). 
Respondents were assured of confidentiality and asked to talk about their status and experience as expatriates. The interviews lasted between 60 and 120 minutes and were conducted in English as this is the lingua franca for business in Dubai (Rettab, Brik \& Mellahi, 2009). The 41 interviews were recorded and transcribed, apart from three in which the interviewees refused permission for tape-recording and intensive notes were taken. Interviews were conducted according to a specific protocol (Appendix 1) developed from the preceding review of the literature on expatriation in general and on the emerging Gulf countries in particular (Atiyyah,1996; Shah, 2004; Lan, 2006; Al-Waqfi, and Forstenlechner, 2014; Cerdin \& Brewster, 2015). Our data collection was shaped progressively in an iterative constant comparison and recursive interplay between rich data and emerging conceptual insights that can be related to existing theories and also allowed us to create new theoretical insights (Doz, 2011). They provide the substance of the disciplined imagination process central to theory building (Weick, 1989). In addition, our inductive approach was more faithful to the richness of the phenomenon being researched than deductive methods could be (Doz, 2011).

\section{Coding and template generation}

This study used template analysis, a qualitative research approach (King, 2004). The simultaneous data collection, coding and analysis enabled us to develop a template through which the textual data set can be interpreted. Drawing on existing literature, the researchers started with an initial template based on the topic of interest and a preliminary analysis of the early interviews. The analysis of the whole data set then enabled the development of the final template that was used to draw the research themes. In this respect, interview questions presented the best starting point in template analysis and served as higher-order codes (King, 2004). The interviews were then used to complement, support or replace those higher-order codes. 
All interviews were coded. Two methods have been suggested (King, 2007) to improve the quality and reliability of the coding process: quality checks and reflexivity. So, the researchers developed a version of the coding scheme beginning with an initial set of several codes with definitions, grouped in categories. Coding our data required sufficient knowledge of the subject matter in question to enable identification of the subtle meanings in the data. The researchers discussed the coding scheme several times with practitioners in the field. Based on the discussions, codes and definitions were clarified (Campbell, Quincy, Osserman \& Pedersen, 2013).

\section{FINDINGS}

Our findings indicate three different categories of expatriates in the UAE, with significant differences between them. These groups are distinguished by their employment status: higher executive and senior management positions, middle- and lower-management positions, and operational positions. In this section, we report particularly the different human resource management practices concerning these distinct expatriate groups.

\section{General structure of expatriates in $U A E$}

First, higher- and senior management positions are mainly filled with nationals or expatriates from Western countries or with an educational background in a Western country, the subject of most research into expatriation to date. Here, nationality is a critical indicator in managing expatriates in the Gulf region. In several interviews, the relationship between nationality and position was outlined:

I am a white face. In Dubai, I have realized there is a strong social hierarchy. At the very

top, there are Emiratis, followed by Westerners, white faces. Under that there are Arabs, 
underneath the Arabs there are Indians, Pakistanis, Bangladeshis, Filipinos, Ethiopians. Just consider the question: how many senior (board-level) Filipinos have you seen in companies you were working with? (Harold, head of SHRM)

Second, throughout the interviews, the middle- and lower-management positions are filled with expatriates from other Arab countries and from India. It was frequently reported that, as one person in this group put it:

I do not have clear evidence, but it is very obvious that your nationality has an impact on your position in the organisation. At the middle-management level, there are many Arabs due to their ability to speak English and Arabic. In addition there are many Indians because Indians are willing to work for lower salaries than others. I know that Europeans would not work under the same conditions as we do. (Razan, accountant)

Third, operational-level positions are mainly filled with expatriates from the Philippines, Bangladesh, India, Ethiopia and other Asian and African countries:

Apparently, there are only certain nationalities working at the operational level. For example, in the hospital, there are local doctors but you would not find any local nurses (Rubi, nurse)

So, the three major categories of expatriates are to a considerable extent nationality based. There are also major differences in the human resource management of these expatriates in the UAE, a form of HRM architecture (Lepak \& Snell, 2002) but with a different rationale. As is well documented in the literature on expatriation (Carr, Inkson \& Thorn, 2005; Oltra, Bonache \& Brewster, 2013), expatriates from Western countries tend to conform to the well-established image of privileged foreign employees. In this regard, expatriates in senior management positions in the 
Gulf reflect the picture of the white, male senior manager living and working in a foreign country, with his family if he has one, to enhance his standard of living and his future career.

High skilled professionals in senior management roles

Many of the respondents within this group highlighted the financial benefits and the experience in an emerging economy as important aspects of their time in the UAE:

The combination of working in a dynamic emerging market and the associated financial rewards were critical to my decision to move to the Gulf. The tax-free environment attracts many expatriates from Europe and North America. I had the great opportunity to be part of a company from scratch. I consider my experience in the UAE as critical to my future career and growth. (Alex, VP strategic management)

The literature does not fit so well the skilled assigned and self-initiated expatriates. As outlined in some of the texts (Andresen et al., 2014; Al Ariss et al., 2015), this group of highly skilled professional expatriates in the UAE enjoy the privileges of receiving lucrative compensation packages and moving to new employers and new countries as they wish. A specification of the regional context, job security and the connection between employment contract and resident visa are major concerns of expatriates of this type. For instance, their careers end whenever there is an Emirati able and willing to work in the same position. One respondent outlined the career limitations in the following way:

I have reached the highest level within my career here. The next higher position is reserved for an Emirati. Obviously, the situation is frustrating and it is not very motivating. (Andy, head of talent management) 
In general, locals want to work in the government sector in more senior positions. Only young and lower-educated locals would work as an executive or assistant. (Alia, assistant)

Another respondent had had direct experience of Emiratization:

In my last company, I and many of my colleagues lost our jobs because of the Emiratization policy. I was lucky to find another job. I expect that many foreigners will have to leave their jobs because more Emiratis will need a job. (Berry, assistant manager)

Other respondents mentioned the effects of Emiratization on job security in various ways;

Job security is a big issue in the Gulf. The number of locals is growing and it is likely that many jobs in senior positions will be occupied by Emiratis. (Lucia, senior marketing manager)

Like all expatriates, employees in this group require 'No Objection Certificates' (NOCs), a legal document issued by the employer to support or restrict expatriates. Respondents described these as a necessity in the event of seeking additional employment, moving to a new employer within the contract period or obtaining a driving license or in order to obtain a license to purchase liquor. However they are readily available for this group:

I would require a NOC if I wanted to work part-time in an additional company. (Omar, marketing manager)

When I decided to apply for a driving license, I was asked to get first a NOC from my employer. I know that we also need a NOC for changing our bank or applying for a loan (Ramin, team leader)

I need a NOC from my employer in order to obtain a license for purchasing liquor. It is my employer's choice whether or not to issue the NOC. (Martin, engineer) 
However, these expatriates are entitled to move to another employer, or resign and return to their home country, at any time. In this and other ways, highly skilled expatriates in the UAE exhibit many similarities with expatriates in other regional settings, although aspects of their situation, including regional peculiarities such as Emiratization as a career-limiting factor or the issues surrounding NOCs, have not been captured by the literature from other regions.

\section{Expatriates in middle - management roles}

In contrast to senior Western managers, semi-skilled expatriates in middle-management roles reflect a culturally diverse background. More specifically, these administrative positions are filled by those from North African and other Middle Eastern Arab countries, Indians, Pakistanis and those from other Asian countries. In contrast to the white, male, middle-aged high-skilled professional, this type of expatriate is diverse in gender, in age and in international experience (see Table 1 for more details). As with the high-skilled professionals, a direct employment contract governs the relationships of expatriates in middle- and lower-managerial positions to their employers.

While high-skilled professionals plan to stay for a limited period of time, expatriates in middlemanagement positions plan to stay as long as possible in the UAE:

We are planning to stay as long as possible. The basic education of the children should be completed and our savings need to be sufficient for a comfortable life back home. (Zain, assistant manager)

The immediate family of expatriates of this type may be located in the UAE or their home countries. Factors such as income or size of family influence the expatriates in their decisions relating to where their families live: 
My wife stays with me here. Our three daughters stay with their grandparents in Kerala and study there. Education is expensive in Dubai und we would not be able to send them to a good school and save money at the same time. (Arjeet, bank employee)

Unlike the senior managers, many of these expatriates send money regularly to their home countries. These expatriates seek to fund their living expenses in the UAE and support their families in their home countries at the same time.

While experience in an emerging market plays a major role in the decisions of high-skilled expatriates to move to and work in the Gulf region, expatriates in middle-management positions also appreciate the safe and secure environment:

The UAE is a safe and free country. It is a good place to live in and my kids will benefit from it. (Imran, executive secretary)

For this group, moving to a new employer or returning to their home country is generally possible providing certain conditions are met, in line with the UAE's labour law (UAE Labour Law, 1980):

Yes, I can switch to a new company, but I have to complete my contract period of two years and leave the current employer on good terms. (Nada, executive secretary)

However, members of this group are aware of the relationship between nationality and position and the impact that has on their marketability:

Nationality is important to get a good job and a good payment. (Hikmat, manager)

This also affects relationships within the organization. Another respondent described the social hierarchy in the organizations as follows: 
A manager would never shout at a European employee. Their situation is different. It is not a secret that they are paid better. Bottom line, your nationality often indicates your position. (Rifat, manager)

Overall, our results show that the human resource management of highly skilled expatriates differs between the senior executive and middle-management levels. While the first group live and work as privileged experts under enhanced terms and conditions, expatriates in middle-management roles, of different nationalities, experience poorer terms and conditions, less freedom and more restrictions. They are different people, in different circumstances, with different objectives, and they experience different treatment.

\section{Expatriates in menial and manual roles}

However, our investigation exposes the existence of an additional type of expatriate that has not yet been explored in the literature. More specifically, this group of expatriates consists of individuals from developing Asian, and occasionally African, countries with limited international experience. They may be male or female, depending almost entirely on the jobs that they do. A direct employment contract or employment through a third party governs the relationship between these expatriates and their employers. Some of them arrive from their home countries as SIEs, but most are recruited through agencies in their home countries and brought to the Gulf countries to do specific jobs. Nearly all that we spoke with send money back home.

In contrast to the two forms of expatriation discussed above, these expatriates receive compensation only; there are no additional allowances:

I can decide where to live but I do not get any accommodation allowances. Because of the high rent costs, I live in a shared accommodation. (Lola, nail technician) 
Other respondents mentioned that accommodation is often provided by the employer:

We are all living in shared rooms provided by the company. The company bus drops us at work and picks us up after the shift. (Jose, restaurant cashier)

Further, while expatriates in the two categories already discussed plan to stay longer in the Gulf region, these expatriates aim to stay for a relatively short period of time. Several reasons influence this type of expatriates in their decision to live and work in the Gulf countries:

I want to get married and need to save enough money for my marriage and for a house. It is easier for me to find a nice girl who wants to marry me if I have my own house. (Shekar, server)

The need to support the family, weak economies, and poor employment markets drive these expatriates to come to the UAE. The family situation in their home countries is a critical factor impacting on their decision to come and the duration of their stay in the Gulf countries:

I have three kids living with my mom in Indonesia. They are three, eight and twelve years old. My husband left us. I do not know how long my mother will be able to take care of the kids. But I have to be here to earn enough money to feed them. What can I do? (Marlina, housemaid)

I am here to support my family. My mother is sick and needs to see often the doctor. This is expensive and I pay for her expenses. (Alia, restaurant waiter)

The families of this group of expatriates do not accompany them to the UAE - they continue to live in their home countries. Therefore, distance becomes a major concern:

My contract is for two years, I have to complete it in order to be able to travel to my country. It is very difficult for me not seeing my children more often. (Cero, cashier) 
The ambition of these expatriates to do better for their children, particularly to provide a better education for them, was outlined in several interviews:

I want my children to be educated and to have a better future than me. This is the reason why I am here. (PJ, cashier)

In respect of the length of their stay in the UAE, the respondents stated their intention to stay as long as it is necessary, but they appreciate that they may have little say in the matter:

It is not clear yet. After completing the contract period of two years, I hope my company will extend my contract. We will see. In general, I want to stay as long as required to save money. (Nura, house keeper)

The decision-making power of employers is a key concern for this cluster of expatriates. For example, the expatriate can only switch jobs, even at the end of the contract, if the current employer will issue a NOC to enable the expatriate to move:

If I want to change my job, I need a NOC. It is up to my employer to issue a NOC. Currently, I am about to complete my two years, but my company does not want to give me the NOC. He wants me to stay with the same company. I know I can make more money somewhere else but I will not be allowed to. In this case I need to leave the UAE. Back in Nepal, I can try to find another job in the Gulf in order to come back. (Max, cleaner)

If the current company has no intention of allowing the expatriate to move to another employer, it can request a ban restricting the mobility of the employee. In other words, moving within or even after the completion of the contract period of two years can only be done with the agreement of the original employer.

Emiratization has no impact on the positions of these expatriates: 
I am not sure what Emiratization exactly is, but I haven't seen any local as a cashier or waiter. (Hassan, waiter)

Locals do not want to work at the operational level, where physical work is required. They want positions as managers, engineers or doctors. (Maricel, nurse)

While high-skilled professionals and expatriates in middle-management roles view job security and increasing cost of living as key challenges, these lower-level expatriates are concerned about the increasing cost of living and personal isolation as key factors influencing their well-being and psychological status:

It is becoming more difficult to send money home because rent and cost of living is increasing and life is very lonely here. My life consists of work and sleep. I miss my family every day. (Mubasa, security agent)

Additionally, expatriates of this type deal with challenges unknown to the higher- and middle-level expatriates discussed above. While comprehensive health insurance is provided to skilled professionals and their immediate family members, expatriates in middle management are offered health insurance for the expatriate only, excluding family members. Though the provision of adequate health insurance is mandatory in the UAE, expatriates in manual and menial roles are often not provided with health insurance:

None of us has health insurance. If I am sick, I will go to the pharmacy to buy medicine. In the case I need to see a doctor, I will go to visit a doctor in a cheap hospital. Usually government hospitals are cheaper than the private hospitals. (Jesse, beautician)

\section{DISCUSSION}


In summary, our in-depth interviews identified the existence of three quite separate types of expatriate, two of which (middle- and lower-level expatriates) have not been the focus of much previous work and one of which (lower-level expatriates) has been more or less entirely hidden in the IHRM literature. In contrast to the few available publications address the issues surrounding expatriation (see e.g. Zachariah, Prakash \& Rajan, 2004, Naithani \& Jha, 2009; Malecki \& Ewers, 2007) our study captures details and differences among expatriates in the UAE. If they have been discussed at all it is under the rubric of the migration literature: but these respondents are not migrants: they do not expect to, and indeed would not be allowed to, settle in the UAE. They are expatriates but of a different kind. Conceptually, we can conceive of these hidden expatriates as in Figure 1.

\section{$<<$ Place figure 1, here $>>$}

The specific context and environment of the UAE leads directly to the need for extensive expatriation and to the kind of expatriates that are employed. Organizations have a different human resource strategy for each kind of expatriate and these are combined into an overall organisational strategy for expatriation, allowing the organisation to change the balance between the groups as needed. Eventually, of course, but not included here, with Emiratization, this will be part of an overall corporate human resource management strategy.

The specific variations between the three categories are summarised in Table 1.

\section{<<Place table 1, here >>}

The data collected through in-depth interviews indicates that expatriation in the Gulf regions is unlike that so far identified elsewhere. Hence, the notion of expatriation has been extended in serval ways. Our findings indicate the complexity and broaden the notion of 'expatriation'. An alternative 
approach would be to ignore these hidden workers in discussions of expatriation and develop a different terminology for them. Since they are part of the human resource management policies and practice of the organisations operating in the Gulf we believe it is better to widen the category. Although it is important for these organisations to have a coordinated and coherent approach to HRM for all their workers, the national context, including cultural conditions, legal restrictions and Emiratization policies, all vary with the type of expatriate and this poses major challenges to the IHRM process.

The hidden expatriates, in particular, represent a cluster not covered in previous discussions of AEs, SIEs or migrants. They are SIEs, since they have chosen to seek jobs in another country, but the motives and the working and living conditions of these hidden SIEs have more in common with some migrants and differ significantly from those of skilled and semi-skilled expatriates. These hidden expatriates account for many positions across the Gulf region and their presence is an important factor within its society and within the economic development of the region. They are generally young, a mix of men and women, coming mainly from developing countries and working in lower-management, manual and menial roles across industries. Furthermore, while Emiratization is a major concern of skilled professionals and a minor concern of expatriates in middle-management roles, it is not relevant to hidden expatriates. The human resource management of hidden expatriates diverges in many ways from expatriation management in the IHRM literature.

\section{LIMITATION AND FUTURE RESEARACH}

Our study has a number of limitations that we do not believe affect its main findings, but which point the way for further research in this area. First, our focus on the UAE as a single country could 
be extended to explore the context of hidden expatriates in other GCC or similar countries, using the same lens and drawing comparisons between then and between them and more developed societies. Second, although our sample was unique and included a wide range of different expatriates, we only had 41 respondents, and although sample size for this kind of research should be evaluated on the data saturation point rather than sample size (Ezzy, 2002; Gummesson, 1991) and our analysis had reached saturation, more responses would be better.

In light of our findings, we encourage scholars to advance the notion of hidden expatriates in their research agendas. Anecdotal evidence from many other countries, even developed countries, indicates that, while the context may be different, there may well be hidden expatriates, particularly those performing similar manual and menial roles as maids and waiters, in many more developed societies. There is still much to learn about them, and our understanding would benefit from further empirical studies into their situation and their management.

\section{MANGERIAL IMPLICATIONS}

Sparrow (2009) argues that the merger of research and professional expertise has had a crucial impact on the development of HRM-relevant policies and procedures. This perspective becomes even more vital in a regional context where there is limited theoretical and practical expertise (Afiouni et al., 2013), which is true not only for UAE-based organizations but also for multinational enterprises working in the region.

Drawing on our in-depth interview results, we identified the existence of three main clusters of expatriates. While the first cluster of expatriates experience sophisticated and tailored HRM practices satisfying their particular needs, and they fit with the literature on most issues, it seems 
from the accounts of the recipients that HRM policies and practices for the middle-level and hidden expatriates have developed incrementally and non-strategically. Further, there is no evidence of any serious attempt to combine the three sets of policies into a coherent strategy. Managers and politician may have to sharpen their attention toward expatriates in middle-management roles. More attention is needed to manage, motivate and retain these expatriates. Additionally, policymakers and managers might develop more strategic and less ad hoc policies for the recruitment, deployment and management of hidden expatriates in order to go beyond focusing on labour supply alone to ensuring effective and coherent human resource management.

\section{REFERENCES}

Abdul Malek, M., Budhwar, P. and Reiche, S. B. (2015). 'Sources of support and expatriation: A multiple stakeholder perspective of expatriate adjustment and performance in Malaysia'. International Journal of Human Resource Management, 26:2, 258-276.

Adler, N. J. (2002). 'Global Managers: No longer men alone'. International Journal of Human Resource Management, 13:5, 743-760. 
Al Ariss, A. and Crowley-Henry, M. (2013). 'Self-initiated expatriation and migration in the management literature: Present theorizations and future research directions'. Career Development International, 18:1, 78-96.

Al Ariss, A., Cerdin, J.-L. and Brewster, C. (2015). 'International Migration and International Human Resource Management', in Dickmann, M., Brewster, C., \& Sparrow, P. R. (eds), Contemporary HRM Issues in Europe (3rd edition). London: Routledge.

Al-Ali, J. (2008). 'Emiratisation: Drawing UAE nationals into their surging economy'. International Journal of Sociology and Social Policy, 28:9/10, 365-379.

Al-Waqfi, M. A., and Forstenlechner, I. (2014). 'Barriers to Emiratisation: The role of policy and design and institutional environment in determining the effectiveness of Emiratisation'. International Journal of Human Resource Management, 24:2, 167-189.

Ando, N., \& Paik, Y. (2013). 'Institutional distance, host country and international business experience, and the use of parent country nationals'. Human Resource Management Journal, 23:1, 52-71.

Andresen, M., Al Ariss, A. and Walther, M. (2013). Self-Initiated Expatriation: Mastering the Dynamics. New York: Routledge.

Andresen, M., Bergdolt, F., Margenfeld, J. and Dickmann, M. (2014). 'Addressing international mobility confusion - Developing definitions and differentiations for self-initiated and assigned expatriates as well as migrants'. International Journal of Human Resource Management, 25:16, $2295-2318$.

Atiyyah, H. S. (1996). 'Expatriate acculturation in Arab Gulf countries'. Journal of Management Development, 15:5, 37-47. 
Baruch, Y., Dickmann, M., Altman, Y. and Bournois, F. (2013). 'Exploring international work: Types and dimensions of global careers'. International Journal of Human Resource Management, 24:12, 2369-2393.

Biemann, T. and Andresen, M. (2010). 'Self-initiated Foreign Expatriates versus Assigned Expatriates: Two distinct types of international careers?' Journal of Managerial Psychology, 25:4, 430-448.

Black, J., Gregersen, H. and Mendenhall, M. (1992). “Toward a theoretical framework of repatriation adjustment'. Journal of International Business Studies, 23:4, 737-758.

Bonache, J. (2006). 'The Compensation of Expatriates: A review and a future research agenda', in Stahl, G. and Björkman, I. (eds), Handbook of Research in International Human Resource Management, Cheltenham: Edward Elgar.

Bonache-Perez, J. and Pla-Barber, J. (2005). 'When are international managers a cost effective solution? The rationale of transaction cost economics applied to staffing decisions in MNCs'. Journal of Business Research, 58:10, 1320-1329.

Boudin, L. B. (1960). Involuntary loss of American nationality. Harvard Law Review, 1510-1531.

Bozkurt, Ö., \& Mohr, A. T. (2011). 'Forms of cross-border mobility and social capital in multinational enterprises‘. Human Resource Management Journal, 21;2, 138-155.

Caligiuri, P. M., and Colakoglu, S. (2007). 'A strategic contingency approach to expatriate assignment management'. Human Resource Management Journal, 17:4, 393-410. 
Campbell, J. L., Quincy, C., Osserman, J., \& Pedersen, O. K. (2013). Coding In-depth Semistructured Interviews: Problems of Unitization and Intercoder Reliability and Agreement. Sociological Methods \& Research, 42(3), 294-320.

Carr, S. C., Inkson, K. and Thorn, K. (2005). 'From global careers to talent flow: Reinterpreting 'brain drain'“. Journal of World Business, 40:4, 386-398.

Cerdin, J.-L., Abdeljalil- Diné, M. and Brewster, C. (2014). 'Qualified Immigrants' Success: Exploring the motivation to migrate and to adjust'. Journal of International Business Studies, 45:2, $151-168$.

Cerdin, J. L and Selmer, J. (2014). 'Who is a Self-initiated Expatriate? Towards conceptual clarity of a common notion'. International Journal of Human Resource Management, 25:9, 1281-1301.

Chammartin, G. M. F. (2004). 'Women migrant workers' protection in Arab League States'. GENDER AND MIGRATION IN ARAB STATES, 8.

Cheng, H.-L.and Lin, C. Y. Y. (2009). 'Do as the large enterprises do? Expatriate selection and overseas performance in emerging markets: The case of Taiwanese SMEs'. International Business Review, 18:1, 60-75.

Chenitz, W. C., and Swanson, J. M. (1986). From Practice to Grounded Theory: qualitative research in nursing. Prentice Hall. Menlo-Park, CA.

Collings, D. G., Scullion, H. and Morley, M. J. (2007). 'Changing Patterns of Global Staffing in the Multinational Enterprise: Challenges to the conventional expatriate assignment and emerging alternatives'. Journal of World Business, 42:2, 198-213. 
Dorsch, M., Suutari, V and Brewster, C. (2012). 'Research in Self-Initiated Expatriation: History and future directions', in Andresen, M., Al Ariss, A., Walther, M., \& Wolff, K. (eds), Self-Initiated Expatriation: Mastering the Dynamics. New York: Routledge.

Dowling, J., Festing, M. and Engel, A. D. (2008). International Human Resource Management (5th ed.). Melbourne: Thomson.

Doz, Y. (2011). 'Qualitative research for international business'. Journal of International Business Studies, 42:5, 582-590.

Ezzy, D. (2002). Qualitative Analysis: Practice and Innovation. London: Routledge.

Federal Competitiveness and Statistics Authority. Available at www.uaestatistics.gov.ae (accessed 14 February 2015).

Forstenlechner, I. (2010). 'Exploring expatriates' behavioural reaction to institutional injustice on host country level‘. Personnel Review, 39:2, 178-194.

Forstenlechner, I. and Rutledge, E. (2010). 'Unemployment in the Gulf: time to update the "social contract”. Middle East Policy, 17:2, 38-51.

Forstenlechner, I. and Mellahi, K. (2011). 'Gaining legitimacy through hiring local workforce at a premium: The case of MNEs in the United Arab Emirates'. Journal of World Business, 46:4, 455461.

Gergen, K. J. (2012). Toward Transformation in Social Knowledge. Springer Science \& Business Media.

Glaser, B. and Strauss, A. (1967). The Discovery of Grounded Theory. London: Weidenfeld and Nicholson. 
Gummesson, E. (1991). Qualitative Methods in Management Research. Newbury Park, CA: SAGE.

Haak-Saheem, W., Festing, M., \& Darwish, T. K. (2016). 'International human resource management in the Arab Gulf States-an institutional perspective'. The International Journal of Human Resource Management, 1-29.

Harris, H. (2002). 'Think international manager, think male: Why are women not selected for international management assignments?' Thunderbird International Business Review, 44:2, 175.

Haslberger, A., and Brewster, C. (2008). 'The expatriate family: An international perspective'. Journal of Managerial Psychology, 23:3, 324-346.

Hechanova, R., Beehr, T. A. and Christiansen, N. D. (2003). 'Antecedents and Consequences of Employees' Adjustment to Overseas Assignment: A meta-analytic review'. Applied Psychology, $52: 2,213-236$.

Henrich, J., Heine, S. J. and Norenzayan, A. (2010). 'The weirdest people in the world?' Behavioral and Brain Sciences, 33:2-3, 61-83.

Hvidt, M. (2009). 'The Dubai model: An outline of key development-process elements in Dubai'. International Journal of Middle East Studies, 41:03, 397-418.

Kim, H. D. and Tung, R. L. (2013). 'Opportunities and challenges for expatriates in emerging markets: An exploratory study of Korean expatriates in India'. International Journal of Human Resource Management, 24:5, 1029-1050.

King, N. (2004). 2) -Using Interviews in Qualitative Research. Essential guide to qualitative methods in organizational research, 2. 
Konopaske, R., Robie, C. and Ivancevich, J. (2009). 'Managerial willingness to assume traveling, short-term and long-term global assignments'. Management International Review, 49:3, 359-387.

Lan, P. C. (2011). 'White privilege, language capital and cultural ghettoisation: Western high-skilled migrants in Taiwan'. Journal of Ethnic and Migration Studies, 37:10, 1669-1693.

Lepak, D. P. and Snell, S. A. (2002). 'Examining the human resource architecture: the relationship among human capital, employment and human resource configurations'. Journal of Management, $28: 4,517-543$.

Malecki, E. J. and Ewers, M. C. (2007). 'Labor migration to world cities: With a research agenda for the Arab Gulf'. Progress in Human Geography, 31:4, 467-484.

Naithani, P., \& Jha, A. N. (2009). Challenges Faced by Expatriate Workers in the Gulf Cooperation Council Countries. International Journal of Business and Management, 5:1, 98-104.

Oberg, W., 1963. II. Cross-Cultural Perspectives on Management Principles. Academy of Management Journal, 6(2), pp.129-143.

Oltra. V., Bonache, J. and Brewster, C. (2013) 'A new framework for understanding inequalities between expatriates and host country nationals'. Journal of Business Ethics, 115:2 291-310.

Patton, M. Q. (1990). Qualitative Evaluation and Research Methods. Beverley Hills, SAGE publications.

Rettab, B., Brik, A. B. and Mellahi, K. (2009). 'A study of management perceptions of the impact of corporate social responsibility on organisational performance in emerging economies: The case of Dubai'. Journal of Business Ethics, 89:3, 371-390. 
Rodriguez, J. K., and Scurry, T. (2014). 'Career capital development of self-initiated expatriates in Qatar: Cosmopolitan globetrotters, experts and outsiders'. International Journal of Human Resource Management, 25:7, 1046-1067.

Shah, N. M. (2004). 'Gender and labour migration to the Gulf countries'. Feminist Review, (77), 183185.

Showail, S. J., McLean Parks, J. and Smith, F. L. (2013). 'Foreign workers in Saudi Arabia: A field study of role ambiguity, identification, information-seeking, organisational support and performance'. International Journal of Human Resource Management, 24: 21, 3957-3979.

Strauss, A. and Corbin, J. M. (1997). Grounded Theory in Practice. SAGE. New York.

Suddaby, R. (2010). 'Challenges for institutional theory'. Journal of Management Inquiry, 19:1, 1420.

Suutari, V. and Brewster, C. (2000). 'Making their own way: International experience through selfinitiated foreign assignments'. Journal of World Business, 35: 4, 417-436.

Tahvanainan, M., Worm, V. and Welch, D. (2005). 'Implications of short-term international assignments‘. European Management Journal, 23:6, 663-673.

Tharenou, P. (2015). 'Researching expatriate types: the quest for rigorous methodological approaches'. Human Resource Management Journal, 25:2, 149-165.

Tung, R. L. (1998). 'American expatriates abroad: From neophytes to cosmopolitans'. Journal of World Business, 33:2, 125-144. 
Vaiman, V. and Brewster, C. (2015). 'How far do cultural differences explain the differences between nations? Implications for HRM'.International Journal of Human Resource Management, 26:2, $151-164$.

Haslberger, A. and Vaiman, V. (2013). 'Self-initiated expatriates: a neglected source of the global talent flow', in Vaiman V and Haslberger, A. (Eds) Talent Management of Self-Initiated Expatriates, Palgrave Macmillan.UK.

Varma, A., Toh, S. M. and Budhwar, P. (2006). 'A new perspective on the female expatriate experience: The role of host country national categorization'. Journal of World Business, 41:2, $112-120$.

Weick, K. E. (1989). 'Theory construction as disciplined imagination'. Academy of Management Review, 14:4, 516-531.

Whetten, D.A., 1989. 'What constitutes a theoretical contribution?' Academy of Management Review, 14(4), pp.490-495.

World Bank Group (Ed.) (2012). World Development Indicators 2012. Washington, DC: World Bank Publications.

Zachariah, K. C., Prakash, B. A., \& Rajan, S. I. (2004). 'Indian Workers in UAE: employment, wages and working conditions'. Economic and Political weekly, 2227-2234. 